\title{
Contents and Methods: The Reference and Enlightenment of ACCA Professional Ethics Education to China
}

\author{
Jinjian Yang* and Zhedong $\mathrm{Hu}$ \\ Accounting School of Wuhan Textile University, Wuhan Textile University, Wuhan, China \\ ${ }^{*}$ Corresponding author. Email: yjj@wtu.edu.cn
}

\begin{abstract}
Although Accounting Professional Ethics has become a core course in the training of accounting professionals, the professional ethics education of accounting professionals in Chinese universities started relatively late, relative to the social development is a little behind. How to implement the new national education quality standards into practice is also very urgent. As the most well-known ACCA examination for accounting qualification in the world, the content and examination of the moral module have much to be used for reference in the aspects of professional moral requirements, course design and examination methods.
\end{abstract}

Keywords: Professional Ethics Education; ACCA; accounting personnel training.

\section{INTRODUCTION}

Despite the international trade frictions and the rise of national protectionism over the past two years, globalisation and internationalisation are still the order of the day. Standards and rules systems are gradually converging and permeating each other. China's socialist modernisation started later than that of developed Western countries and is still learning from the more mature international system in many areas, especially in accounting-related systems, such as the recent hotspot of personal tax reform, which reflects more humane and individualised differences in standards and is a good example of convergence with the international system. Against the backdrop of rapid economic development and the fast-track construction of systems in the country, the professional ethics of accounting staff have not kept pace, and breaches of professionalism have occurred repeatedly. Financial fraud is still widespread, and even as an independent third-party auditor, significant malpractice is often exposed by the media. It can be said that the improvement of the overall business quality of financial personnel and professional ethics have not been parallel. The proportional growth of the international Big Four firms with $20 \%$ of their business each year is not just a reflection of the higher quality of their business compared to domestic firms, but also of their higher professional ethics and the image of impartiality and professionalism they have established in society and the market. According to Lagarde, "A system with a higher level of ethics is a more stable system. Because ethics breeds trust. And a more stable system leads to more sustainable growth." (Christine Lagarde, 2017) ${ }^{[1]}$

\section{THE NECESSITY OF PROFESSIONAL ETHICS EDUCATION IN THE TRAINING OF ACCOUNTING TALENTS IN COLLEGES AND UNIVERSITIES}

Professional ethics is a guideline for employees to judge whether their behavior is correct or not. An excellent enterprise depends on good professional ethics of employees. The professionalism of accounting staff and their contribution to the value of the enterprise should be proportional, as pointed out by President $\mathrm{Li}$ Shichang of Beijing East Asia International Technical Training Center (Li Shichang, 2008), the value of enterprise employees $=$ professional ethics $\times$ innovation ability + education + professional qualification + scarcity. ${ }^{[2]}$ It can be seen that employee's professional ethics and innovation ability are equally important.

As a professional profession, the accounting profession has been deeply influenced by the licensing examinations (primary, intermediate, advanced and 
CPA, etc.) for a long time. As early as 1998, Premier Zhu Rongji's inscription in the National Accounting Institute was "No false accounting", which put forward the basic requirements for the professionalism of accounting talents, but the training of accounting personnel on professional ethics was integrated into the corresponding theoretical knowledge, and few special courses were offered separately, or there were few practical training courses to consolidate it. The Ministry of Education of the People's Republic of China (MOECC) has also adopted a new approach to the cultivation of professional ethics. ${ }^{[3]}$ This time, the Ministry of Education from the perspective of professional standards, professional ethics education is mentioned as the first article of talent training, and "accounting ethics" is taken as one of the core professional courses, which can be seen from the upper guiding ideology of the importance, which is also in line with the requirements of the times.

\section{ACCA PRACTICE EXAM ON THE CULTIVATION OF PROFESSIONAL ETHICS}

The rocks of other mountains can be used to make a difference. In today's culturally confident world, higher education is still meant to be open and absorbing, constantly enriching and optimising the quality of education. The ACCA, or Association of Chartered Certified Accountants, is the world's most prestigious professional qualification for accountancy professionals. The UK leads the world in terms of metrics and accounting standards, so the institution has always adhered to the philosophy of think ahead, translating the urgent needs of practice or future needs into its specific curriculum.

\subsection{Basic Elements of Professional Ethics}

ACCA adopted the International Code of Ethics for Accountants (including the International Standards for Independence) issued by the International Ethics Standards Board for Accountants (IESBA) in April 2018. However, additional requirements and guidance applicable to ACCA and its members were added to the IESBA Code to meet the ACCA Code of Ethics and Conduct (CEC).The CEC, which is binding on all ACCA members and students, sets out five fundamental ethical principles and provides a framework for addressing ethical issues:

First, Integrity: requires straightforwardness and honesty in all professional and business relationships; Second, Objectivity: does not allow subjective bias, personal conflicts of interest or undue influence to override professional skills or business judgement; Third, Professional competence and discretion: maintains the professional knowledge and skills required to ensure that the client or employer receives competent professional services in accordance with the latest developments in practice, legislation and technology professional services and act with diligence in accordance with applicable technical and professional standards; fourth, confidentiality: respect the confidentiality of information obtained as a result of professional and business relationships and therefore not disclose any such information to third parties without proper and specific authorisation or use the information for personal advertising, unless there is a legal or professional right or obligation to do so. Fifthly, professional conduct: comply with the relevant laws and regulations and avoid any conduct that would be detrimental to professional reputation.

\subsection{Content of Professional Ethics Training}

The Professional Ethics module incorporates realworld business scenarios through interactive digital simulations, thereby developing a broad and in-depth understanding of the following areas. The module consists of six interactive modules: ethics and professionalism; personal work effectiveness; innovation and questioning; business awareness, analysis, evaluation and problem solving; leadership and teamwork; and communication skills. ${ }^{[4]}$

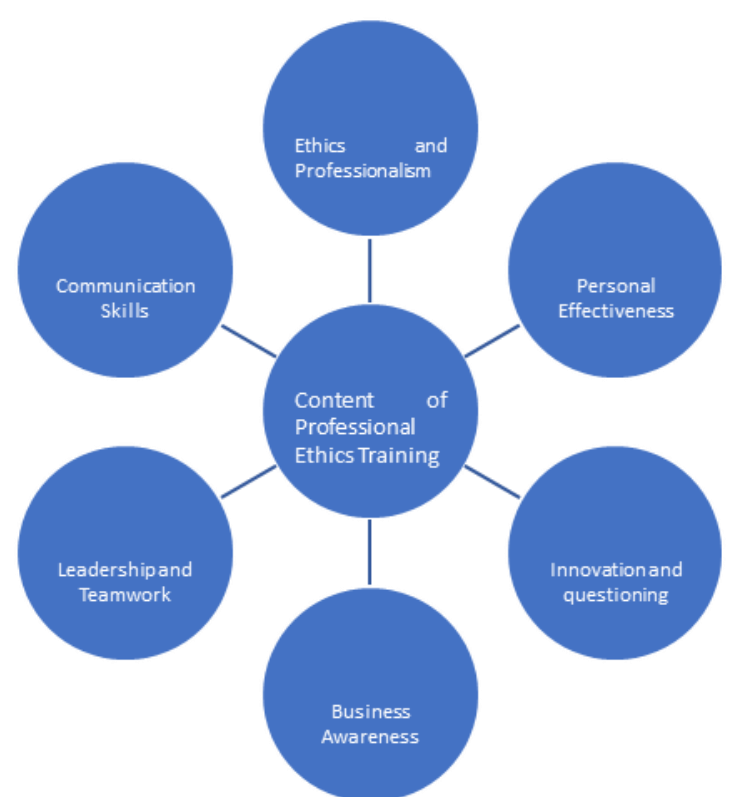

Figure 1 Content of Professional Ethics Training

First, Ethics and Professionalism: This module introduces a broad range of ethical values that underpin all other professional skills and behaviours in the module. This section focuses on some of the theories of ethics, the code of professional ethics that professional accountants should follow, and how to resolve ethical dilemmas. It helps to develop and practise the professional competencies and ethical qualities that are 
critical to the success of a professional accountant's career.

Secondly, Personal Effectiveness: The Personal Effectiveness unit will demonstrate how to maximise the quantity and quality of your work output, as well as how to communicate and interact with others, and how to ensure that you make the most of your resources. This section focuses on personal time management, how to write a $\mathrm{CV}$, organising your time, meetings and how to use IT efficiently, such as how to use spreadsheets for data analysis.

Thirdly, Innovation and questioning: this module will help to understand how to encourage openmindedness and innovative thinking to create or propose imaginative solutions where appropriate, feasible and acceptable, while recognising the limitations of achieving solutions to problems. This section focuses on the thinking and elements of innovation, innovation and competitive advantage, how to promote innovation in the workplace and how to demonstrate professional questioning.

Fourth, Business Awareness, Analysis, Evaluation and Problem Solving: This module focuses on improving participants' ability to look at situations from a commercial or business perspective, to think about the factors that affect business success, and to understand business processes, relationships, risks and costs. This section covers how to exercise your commercial awareness and insight, how to do planning, and to evaluate large amounts of data and come up with appropriate solutions.

Fifth, Leadership and Teamwork: In this module you will learn more about the different types of leadership approaches and characteristics that can be adopted or adapted at any level of the organisation, including how to effectively use inspiration, motivation and support to lead teams to work effectively and efficiently and bring value to the organisation.

Sixth, Communication Skills: This module helps to understand how to communicate effectively with others in a business environment, including principals, clients, colleagues and external organisations. It includes how to write emails, organise meetings, write reports, make phone calls and give presentations.

These six areas are finally integrated into an interactive and comprehensive module, incorporating real-life business situations, where participants will take on real challenges as professional accountants and develop effective solutions.

\subsection{Professional Ethics Are Embedded In the Examination System}

For ACCA members, the ethical requirements are very specific. Membership qualifications are renewed and tests are submitted for the ethics module to meet the high standards of professional ethics required of members. The latest ethics exam module is another ACCA world exclusive, developed by official ACCA bodies in conjunction with employers, and is designed to develop compliance with ethical behaviours in different business situations that can complement business competencies and enable students to achieve success in their careers. One of the exams is 20 hours long and on completion of the module a certificate is awarded which can be presented to current and future employers as a valuable quality assurance. The format of the exam is very flexible and can be studied at any time during the study of the exam subject Strategic Business Leadership at advanced level; a fee is charged for the exam.

\section{CURRICULUM DISCUSSION ON THE CULTIVATION OF PROFESSIONAL ETHICS OF ACCOUNTING TALENTS IN CHINA'S COLLEGES AND UNIVERSITIES}

The module of professional ethics education which is missing in the training system of accounting talents in China's colleges and universities can be borrowed from the curriculum design of this examination, and the revelations are as follows, taking into account the specific educational situation of China.

\subsection{The Requirements of Professional Ethics}

Finance and accounting personnel must strictly require themselves from the ideological point of view, and universities should also establish strict professional ethical requirements in the training of talents, as follows.

First, the noble ideological and moral qualities. To use Marxist ideas, combined with the core values of the new era of scientific socialism to arm their minds, the formation of good social attention to the concept of moral sentiment. Finance and accounting staff at all times to establish a correct outlook on life, world view and values, the national interest in the first place, abide by the principle of objectivity and impartiality, and keep professional secrets.

Secondly, love and dedication, positive and enterprising work attitude. Finance and accounting work very often has a certain normative constraints, and the management of higher departments, cannot fully play their own initiative. However, accounting work is a very important part of society and enterprises, monitoring the changes of funds and assets, and playing a vital role in the social climate and effective management of enterprises. Therefore, universities and colleges should cultivate accounting talents in a prudent manner, so that 
students can love their jobs and be active and enterprising, and maximise their value.

Thirdly, solid business literacy. Accounting and finance work is very hands-on and professional work, universities should adhere to the cultivation of students' business literacy, especially in the area of hands-on skills, to combine theoretical learning and practice, and improve students' professionalism through internships and situational simulations or analysis competitions.

Fourth, integrity and a healthy mindset. Some accounting staff in society seriously lack an objective and impartial attitude, making up false accounting books and statement vouchers, etc., seeking to maximise local and personal interests, and contributing to the unhealthy trend of corruption. Colleges and universities need to uphold the spirit of truthfulness in the cultivation of students' personalities, to be able to judge things correctly and to maintain a healthy and good mentality.

\subsection{Content of Professional Ethics Education}

Firstly, on the spiritual level, the awareness of integrity and professional conduct, the introduction of the requirements of accounting standards should be based on the importance of humanistic qualities, the establishment of the concept of the rule of law, civic awareness and scientific attitude. While respecting the national standards, the general education courses in ethics and humanities should strengthen the understanding of domestic accounting standards and also adapt to the introduction of international standards and guidelines, so that students' horizons can be constantly improved.

Secondly, professional quality. Students should have good expertise and skills in accounting and finance, the basic ability to analyse and solve problems, adherence to professional ethics, a sense of career responsibility and a rigorous working attitude. This can be continuously strengthened from professional courses, proficiency in qualitative and quantitative methods, proper analysis of information through keen insight, and sound advice for decision support and risk management.

Thirdly, physical and mental qualities and general competencies. Specialised psychological quality education should be provided for students to correctly perceive the relationship between the laws of society and the harmonious development of man and nature. Dealing with interpersonal and communication skills and continuously improving the overall quality of students through team writing, language and written communication skills in the curriculum and practical sessions.

\subsection{Ways and Means of Professional Ethics Education}

First, the whole stage of professional ethics education. There should be corresponding professional ethics education for accounting students in different stages of university. In addition to the two courses and the corresponding psychological quality education, for professional education, different courses should be embedded at different stages. At the freshman level there should be a curriculum match for the professionalism aspect of accountancy. In the second year, modules on professional ethics should be embedded in the intermediate financial accounting and auditing courses. In the third and fourth year, students' professional ethics should be reinforced through internships, practical training courses or situational simulations. The whole undergraduate level is integrated.

Second, diversification of assessment forms. The combination of assessment and education. Assessment is only a means to an end; the improvement of professional ethics education is the real goal. In professional ethics education, both examinations can be used to make students remember the knowledge points of professional ethics education, and interviews, practical courses and competitions can also be used to diversify the forms of education and to teach and entertain students, so that they can vividly and deeply grasp the meaning of ethical literacy in different contexts.

It is worthwhile to learn from ACCA's advancement, not only from the academic education of universities, but also from the future licensing examinations and training stages, to improve the professional ethics of accountants to meet the rapid development of society.

\section{ACKNOWLEDGMENTS}

Project Support: Wuhan Textile University 2021 University-level Education and Teaching Project

Project Title: Research on the cultivation path and optimization of international accounting talents in the context of convergence of accounting standards

Project No.: 2021JY018

\section{REFERENCES}

[1] Christine Lagarde. The magic formula of ethics in finance [J]. Chief Financial Officer, 2017(01):7073.

[2] Li S. C. Exploring a life in finance--Side note on ACCA Career Development Forum 2008[J]. Finance and Accounting Learning, 2008(12):7879. 
[3] National Standards for Teaching Quality in Business Administration (Accounting Major) [A]. National standards for teaching quality in higher education, 2018:849-853.

[4] Professional Ethics and Professional Skills Module http://cn.accaglobal.com/info/affiliate/careerprofes sion-120-905.html [EB/OL]. 2018-12-17 